\title{
Evaluation of arthropods diversity on apple crop ('Red Delicious') in Sidi Naâmane area (Tizi-Ouzou), Algeria
}

\author{
Dyhia GUERMAH ${ }^{* 1}$, Ferroudja MEDJDOUB-BENSAAD ${ }^{1}$ and Malika AOUAR-SADLI ${ }^{1}$
}

Received December 01, 2018; accepted March 08, 2019.

Delo je prispelo 01. decembra 2018, sprejeto 08. marca 2019.

\begin{abstract}
Arthropods fauna contributes significantly to biodiversity and ecosystem functioning. In this context an inventory of arthropods communities upon ecological apple plot, 'Red Delicious' is realized in Sidi Naâmane area (Tizi-Ouzou, Algeria). This study was conducted from November 2014 to December 2015, by combining different sampling techniques: sweep net, barber pot and colored traps.

The results showed a total of 113 species distributed into 64 families, 10 orders and 3 classes, which are Arachnida, Enthognata and Insecta. The colored traps sampling method allowed collecting 63 species (with $30 \%$ of pests), among which Coruna sp. is the most noted, with relative abundance of $6.77 \%$. The barber traps sampling method allowed collecting 56 species (with $42.88 \%$ of pests), among which Harpalus paratus Casey, 1924 is the most frequent, with $6.51 \%$. The sweep net sampling method allowed collecting 80 species (with $33 \%$ of predators), among which Coccinella algerica Kovár. 1977 is the most noted, with relative abundance of $5.32 \%$. The Shannon diversity index values ranged from 5.33 bits for the Barber pot traps method to 5.58 bits for colored traps and 5.90 bits for the sweep net technique.
\end{abstract}

Key words: inventory; arthropods; apple; 'Red Delicious'; Sidi Naâmane; Algeria
IZVLEČEK

\section{OVREDNOTENJE RAZNOLIKOSTI ČLENONOŽCEV NA JABLANI ('Red Delicious') V OBMOČJU SIDI NAÂMANE (TIZI-OUZOU), ALŽIRIJA}

Favna artropodov prispeva $\mathrm{v}$ veliki meri $\mathrm{k}$ raznolikosti in delovanju ekosistemov. V tem smislu je bil izveden popis členonožcev v sadovnjaku rdečega delišesa ('Red Delicious') v območju Sidi Naâmane (Tizi-Ouzou, Alžirija). Raziskava je bila opravljena od novembra 2014 do decembra 2015, s kombinacijo različnih vzorčevalnih tehnik kot so lovljenje $\mathrm{z}$ mrežo, z lovilnimi lončki in z obarvanimi pastmi.

Celokupno so na vzorčeni površini našli 113 vrst, ki so spadale v 64 družin, 10 redov in v 3 razrede, ki so bili Arachnida, Enthognata in Insecta. Vzorčevalna metoda $\mathrm{z}$ obarvanimi pastmi je dala ulov 63 vrst (s 30 \% škodljivcev), med katerimi so bile vrste iz rodu Coruna sp. najpogostejše, z relativno abundanco $6,77 \%$. Z vzorčevalno metodo lovilnih lončkov se je ujelo 56 vrst (z 42,88 \% škodljivcev), med njimi je bila vrsta Harpalus paratus Casesy, 1924 najpogostejša, z $6,51 \%$. Z metodo lovljenja $\mathrm{z}$ mrežo je bilo ujetih 80 vrst (s $33 \%$ plenilcev), med njimi je bila alžirska polonica Coccinella algerica Kováŕ, 1977 najpogostejša, z relativno abundanco 5,32\%. Shannonov diverzitetni indeks je bil v območju od 5,33 za lovilne lončke, do 5,58 za obarvane pasti in 5,90 za lovlenje z mrežo.

Ključne besede: popis; artropodi; jablana; 'Red Delicious'; Sidi Naâmane; Alžirija

\section{INTRODUCTION}

The apple crop extends to all temperate climates areas of the globe; it is ranked as first fruit trees cultivated worldwide (Chouinard et al., 2000). Fruit trees like any plant species form a favorable environment for the spread of pests and infectious diseases.
Arthropods occupy a special place in the ecosystem, they are good biological indicators, and occupy very diverse ecological niches (Clere and Bretagnolle, 2001).

1 Laboratoire de production, sauvegarde des espèces menacées et des récoltes. Influence des variations climatiques. Département de biologie. Faculté des sciences biologiques et des sciences agronomiques. Université Mouloud Mammeri de Tizi-Ouzou 15000. Algérie; *corresponding author: guermah.dy@gmail.com 
Arthropods can be harmful to crops but also helpful such as parasites and predators involved in regulating populations of pests.

Sustainable arboriculture aims to produce quality fruits with a minimization of negative impacts on the environment and human health, caused by the misuse of pesticides against pests (Dubuis, 2010). Therefore, it is necessary today to develop new methods for protecting apple and consider their negative impacts by implementing new agricultural practices that integrate sound management of pests and respect the balance of environment and human health.
For this, it is fundamental to understand the relationships between insect pests and their host plants and thus know their spatial and temporal dispersion in a region (Debouzie and Thioulouse, 1986).

The objective of the work is to study the arthropod fauna associated with apple crop, and identifying possible predators and parasites that can intervene in the regulation of pest populations in order to envisage a rational control program and more respectful of the environment.

\section{MATERIALS AND METHODS}

This study was conducted in a 'Red Delicious' orchard not subject to treatment by pesticides. The parcel is located in the Sidi Naâmane area (36 $45^{\prime} 29^{\prime}$ ' Nord, 3०59'02', East) (Tizi-Ouzou, Algeria) in a Mediterranean climate characterized by a sub-humid bioclimatic stage with temperate winter.

The study was conducted from November 2014 to December 2015, covering vegetation, flowering and fruiting periods of Malus domestica Borkh. plants.

\subsection{Geographical location of the study area}

The ecological apple orchard is situated in Sidi Naâmane area (Tizi-Ouzou) at $100 \mathrm{~km}$ East from Algiers and $30 \mathrm{~km}$ south of the Mediterranean coasts (Fig.1).

In an orchard of 1600 trees, a plot of 100 trees is isolated for the study. Sampling of arthropod populations was performed by using three methods namely colored air traps (on the foliage), Barber pot and sweep net.

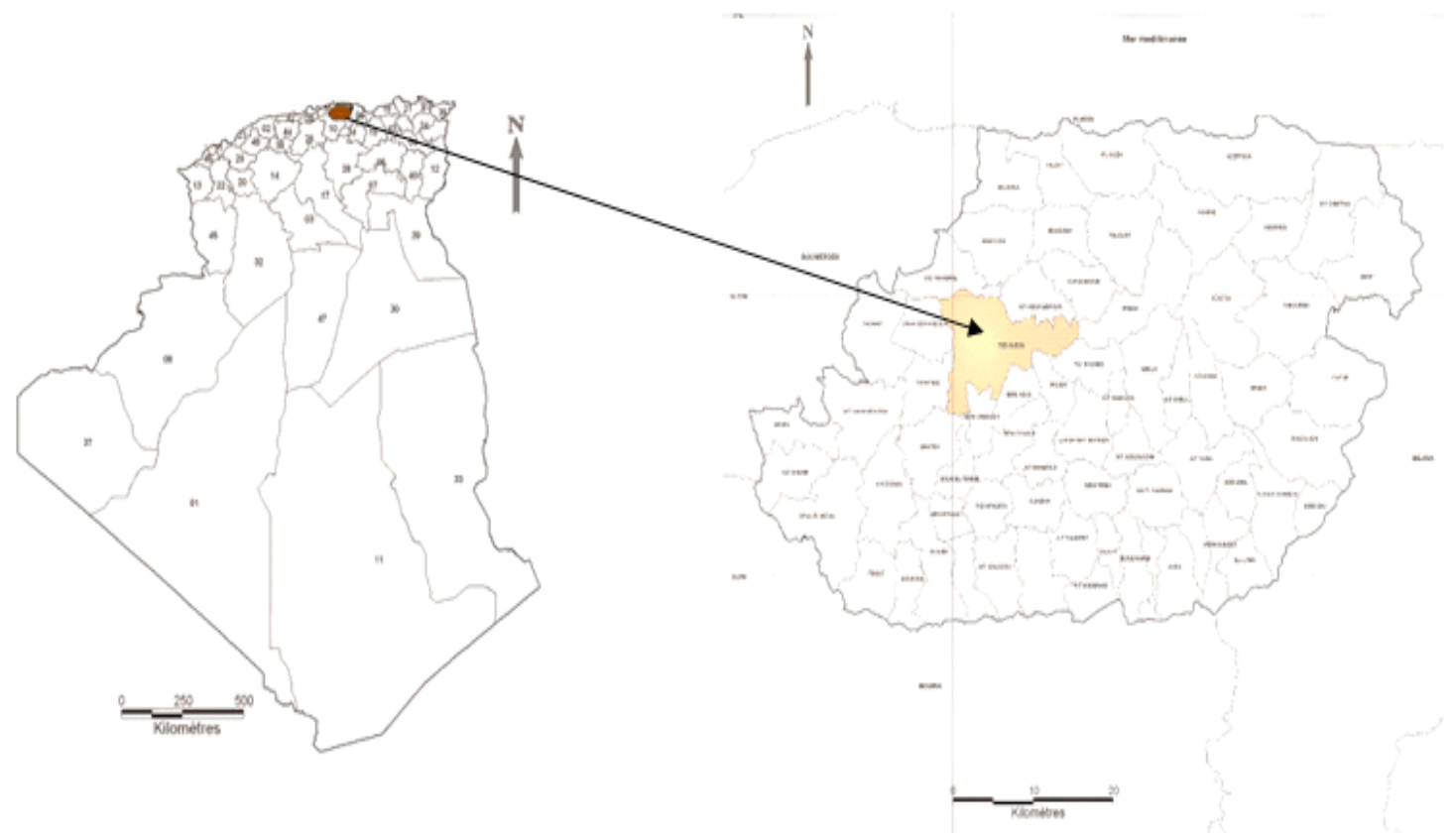

Figure 1: Location of the study area in Algeria (Google maps, 2019) 


\subsection{Sampling methods}

Nine Barber pots were disposed in quadra, filled to $2 / 3$ of their content with soapy water; for collecting walkers arthropod; they are visited once a week. The content was collected and put in jars with labels on which were indicated the date of collection and the trap concerned.

For colored traps, nine yellow basins are suspended by an iron wire to apple trees and filled with soapy water to two-third of their height; for collecting arthropods lodged in the foliage. The water trap is renewed after each removal.

Sweep net moving is applied in herbaceous layer between the rows of the study plot once a week during the study period, by dislodging arthropods hidden in vegetation.

All samples collected in the field are brought back to the laboratory for being sorted and identified under a binocular microscope. The determination of arthropods species, based on morphological characters and their chaetotaxy, was performed by using different identification keys Sergent (1909); (Perrier, 1927, 1932, 1961); (Seguy, 1923, 1924); (Piham, 1986); (Chinery, 1988); (Delvare \& Aberlenic, 1989).

\subsection{Data processing}

For treating the results obtained, different indices were used.
The total wealth is calculated for each sampling method. It is the total number of species that includes the population considered in an ecosystem (Ramade, 2003).

The relative abundance (centesimal frequency) Fc (\%) was also evaluated; it gives the percentage of individuals of a species $\mathrm{Ni}$ relative to the total number of individuals N (Dajoz, 1971).

$\mathrm{Fc}=\mathrm{Ni} \times 100 / \mathrm{N}$

According to Barbault (1981), species diversity is measured by various indexes; the most used is the Shannon-Weaver. It is calculated by the following formula:

$H^{\prime}=-$ qi $\log 2$ qi

H': diversity index expressed in bits units qi: the probability of encountering the species i

The equitability index is the ratio of observed diversity $\mathrm{H}^{\prime}$ to the maximum diversity' $\max : \mathrm{E}=\mathrm{H}^{\prime} / \mathrm{H}^{\prime} \max$ (Blondel, 1979). Knowing that $\mathrm{H}^{\prime} \max$ is calculated using the following formula:

$\mathrm{H}^{\prime} \max =\log 2 \mathrm{~S}$

S: total wealth

H'max: is expressed in bits

\section{RESULTS}

During this study which focused on the inventory of arthropods fauna associated to apple trees in an ecological orchard not subjected to pesticide treatments, 113 species were captured, distributed in 64 families belonging to 10 orders and to 3 classes.

\subsection{Total wealth and relative abundance}

The collected arthropod in a 'Red Delicious' apple plot using different trapping methods allowed us to identify
113 species belonging to three classes: Arachnida, Enthognata and Insecta. The Insecta class is the best represented with eight orders. The total wealth of the species caught by the three trapping methods was 80 species for the sweep net; 63 species for colored traps and 56 species for Barber pots (Table 1).

Table 1: Total wealth of species caught by different sampling methods

\begin{tabular}{cccc}
\hline Traps & Sweep net & Colored traps & Barber pots \\
\hline Total wealth & 80 Species & 63 Species & 56 Species \\
\hline
\end{tabular}

Centesimal frequency $(\mathrm{CF})$ of arthropod orders captured in an apple plot using different sampling methods is shown in Table 2. Centesimal frequency of species identified according to the order, family and gender are presented in Table 3. 
Dyhia GUERMAH et al.

Table 2: Centesimal frequency of arthropod species captured using different sampling methods

\begin{tabular}{llll}
\hline Orders & Sweep net CF \% & Barber pot CF \% & Colored traps CF \% \\
\hline Spiders & 5.32 & 6.51 & 2.19 \\
Collembola & 0 & 7.75 & 0 \\
Neuroptera & 0.25 & 0 & 1.75 \\
Hymenoptera & 36.38 & 17.08 & 37.13 \\
Diptera & 20.03 & 6.69 & 25.3 \\
Heteroptera & 7.35 & 0 & 6.77 \\
Homoptera & 2.66 & 3.52 & 12.23 \\
Coleoptera & 24.84 & 50.35 & 14.63 \\
Dermaptera & 0.38 & 2.29 & 0 \\
Orthoptera & 2.79 & 5.81 & 0 \\
\hline Total & 100 & 100 & 100 \\
\hline
\end{tabular}

The most dominant order recorded for sweep net and colored traps is Hymenoptera with relative abundance of $36.38 \%$ and $37.13 \%$ respectively for Barber potgs,

the most dominant order is Coleoptera with relative abundance equal to $50.35 \%$.

Table 3: Centesimal frequency of arthropod species captured using different sampling methods

\begin{tabular}{|c|c|c|c|c|c|c|}
\hline \multirow{2}{*}{$\begin{array}{l}\text { Classes } \\
\text { Arachnida }\end{array}$} & \multirow{2}{*}{$\begin{array}{l}\text { Orders } \\
\text { Spiders }\end{array}$} & \multirow{2}{*}{$\begin{array}{l}\text { Families } \\
\text { Opilionidae }\end{array}$} & \multirow{2}{*}{$\begin{array}{l}\text { Species } \\
\text { Phalangida sp. Sundevall, } 1833\end{array}$} & \multicolumn{3}{|c|}{ Centesimal frequency $(\%)$} \\
\hline & & & & 0.38 & 0 & 0.65 \\
\hline & & Dysderidae & Dysdera crocata Koch, 1838 & 0 & 1.41 & 0 \\
\hline & & Gnaphosidae & Gnaphosidae sp. Pocock, 1898 & 0 & 0.70 & 0 \\
\hline & & Thomisidae & Thomisus sp. Walckenaer, 1805 & 0.38 & 0 & 0.44 \\
\hline & & Philodromidae & Tibellus sp. Simon, 1875 & 1,52 & 0 & 0 \\
\hline & & Pisauridae & Pisaura mirabilis Clerck, 1757 & 1.14 & 0.53 & 0 \\
\hline & & Salticidae & Salticidae sp. Blackwall, 1841 & 1.52 & 0 & 1.09 \\
\hline & & Lycosidae & Lycosidae sp. Sundevall, 1833 & 0.38 & 3.87 & 0 \\
\hline \multirow[t]{3}{*}{ Enthognata } & Collembola & Entomobryidae & Entomobrya nivalis Rondani, 1861 & 0 & 0.18 & 0 \\
\hline & & & Orchesella cincta Linnée, 1758 & 0 & 2.46 & 0 \\
\hline & & Sminthuridae & Sminthurus viridis Lubbock, 1862 & 0 & 5.10 & 0 \\
\hline \multirow[t]{14}{*}{ Insecta } & Neuroptera & Chrysopidae & Chrysoperla carnea Stephens, 1836 & 0.25 & 0 & 1.75 \\
\hline & Hymenoptera & Apidae & Eucera panonica Linnée, 1758 & 1.65 & 0 & 1.31 \\
\hline & & & Bombus terrestris Linnée, 1758 & 0.38 & 0.53 & 0.87 \\
\hline & & & Panurgus sp. Panzer, 1806 & 0.89 & 0.70 & 3.93 \\
\hline & & & Apis mellifera Linnée, 1758 & 2.92 & 1.58 & 3.27 \\
\hline & & & Eucera longicornis Linnée, 1758 & 0.76 & 0 & 0.44 \\
\hline & & Scoliidae & Colpa quinquecinta Latreille, 1802 & 2.79 & 0 & 1.09 \\
\hline & & & Scolia sp. Fabricius, 1775 & 0.38 & 0 & 0 \\
\hline & & Andrenidae & Andrena sp. Fabricius, 1775 & 1.14 & 0.53 & 3.71 \\
\hline & & Colletidae & Hylaeus meridionalis Forster, 1871 & 0.51 & 0 & 0 \\
\hline & & Pompilidae & Priocnemis sp. Latreille, 1802 & 1.65 & 0 & 2.62 \\
\hline & & Ichneumonidae & Coruna sp. Walker, 1833 & 1.14 & 0 & 6.77 \\
\hline & & & Diplazon sp. Fabricius, 1781 & 0.89 & 0 & 0 \\
\hline & & Tenthredinidae & Tenthredo marginella Linnée, 1758 & 0.76 & 0 & 0 \\
\hline
\end{tabular}


Evaluation of arthropods diversity on apple crop ('Red Delicious') in Sidi Naâmane area (Tizi-Ouzou), Algeria

\begin{tabular}{|c|c|c|c|c|c|}
\hline & Formicidae & Pheidol pallidula Nylander, 1849 & 0 & 0 & 1.09 \\
\hline & & Cataglyphis viaticus Forster, 1850 & 0 & 1.06 & 0 \\
\hline & & Cataglyphis bicolor Forster, 1850 & 0 & 2.99 & 0 \\
\hline & & Aphaenogaster sp. Mayr, 1853 & 0 & 2.11 & 0 \\
\hline & & Messor barbarus Linnée, 1767 & 1.14 & 4.92 & 0 \\
\hline & & Componotus lateralis Olivier, 1792 & 0.25 & 2.11 & 0 \\
\hline & & Plagiolepis sp. Mayr, 1861 & 0 & 0.53 & 0 \\
\hline & Pteromalidae & Pteromalus puparum Linnée, 1758 & 1.77 & 0 & 3.49 \\
\hline & Eupelmidae & Eupelmus sp. Walker, 1833 & 1.39 & 0 & 0.44 \\
\hline & Brachonidae & Cotesia sp. Linnée, 1758 & 0.50 & 0 & 0 \\
\hline & & Brachonidae sp. Latreille, 1829 & 0.25 & 0 & 0 \\
\hline & Vespidae & Lasioglossum calceatum Scopoli, 1763 & 3.42 & 0 & 2.84 \\
\hline & & vespula germanica Fabricius, 1793 & 0.38 & 0 & 0 \\
\hline & & Polistes gallicus Linnée, 1761 & 4.69 & 0 & 2.62 \\
\hline & Sphecidae & Sceliphron destillatorium Klug, 1801 & 0.63 & 0 & 0.44 \\
\hline & Megachilidae & Osmia cornuta Latreille, 1805 & 0.38 & 0 & 0 \\
\hline & & Megachile centuncularis Linnée, 1758 & 1.65 & 0 & 0 \\
\hline & & Megachile fertoni Pérez, 1896 & 0.89 & 0 & 0 \\
\hline & Halictidae & Halictus sp. Latreille, 1804 & 1.14 & 0 & 1.53 \\
\hline & Trichogrammatidae & Trichogramma daumalae Westwood, 1833 & 2.03 & 0 & 0.65 \\
\hline \multirow[t]{22}{*}{ Diptera } & Culicidae & Anopheles sp. Meigen, 1818 & 0.25 & 0 & 2.40 \\
\hline & & Culiseta sp. Felt, 1904 & 0.51 & 0 & 0.65 \\
\hline & & Culex sp. Linnée, 1758 & 0 & 0 & 1.31 \\
\hline & & Culex pipiens Linnée, 1758 & 1.52 & 0 & 3.71 \\
\hline & Ceratopogonidae & Culicoides albicans Winnertz, 1852 & 0.63 & 0 & 0.87 \\
\hline & Calliphoridae & Calliphora vicina Robineau-Desvoidy, 1830 & 1.77 & 0.70 & 1.53 \\
\hline & & Calliphora vomitoria Linnée, 1758 & 0.63 & 0.35 & 0.65 \\
\hline & & Calliphoridae sp. Hough, 1899 & 0 & 0 & 0.44 \\
\hline & & Lucilia ceasar Linnée, 1758 & 1.90 & 1.06 & 2.18 \\
\hline & Tephritidae & Ceratitis capitata Weidemann, 1824 & 0 & 0 & 3.93 \\
\hline & Stratiomidae & Chloromyia formosa Duncan, 1837 & 2.66 & 0.53 & 2.18 \\
\hline & Tabanidae & Chorisops sp. Meigen, 1820 & 1.14 & 0 & 0 \\
\hline & Syrphidae & Melanostoma mellinum Linnée, 1758 & 3.04 & 0 & 0 \\
\hline & & Eristalis tenax Linnée, 1758 & 0.89 & 0.35 & 1.09 \\
\hline & & Syrphus ribesii Linnée, 1758 & 1.01 & 0 & 0.44 \\
\hline & Tipulidae & Tipula oleracea Linnée, 1758 & 1.52 & 0 & 0.65 \\
\hline & & Tipula lateralis Linnée, 1758 & 1.8 & 0 & 0 \\
\hline & Empididae & Empis grisea Fallen, 1816 & 0.76 & 0.53 & 0 \\
\hline & & Empis sp. Linnée, 1758 & 0 & 0 & 0.65 \\
\hline & Muscidae & Graphomya maculata Scopoli, 1763 & 0.51 & 0 & 0.87 \\
\hline & Fannidae & Fannia sp. Robineau-Desvoidy, 1830 & 0 & 0 & 0.44 \\
\hline & Chironomidae & Chironomus plumosus Linnée, 1758 & 0 & 3.17 & 1.31 \\
\hline \multirow[t]{2}{*}{ Heteroptera } & Scutelleridae & Eurygaster maura Linnée, 1758 & 0.38 & 0 & 1.75 \\
\hline & & Eurygaster testudinaria Geoffroy, 1758 & 0 & 0 & 0.87 \\
\hline
\end{tabular}




\begin{tabular}{|c|c|c|c|c|c|c|}
\hline & & Pentatomidae & Rhaphigaster nebulosa Poda, 1761 & 0.63 & 0 & 0 \\
\hline & & & Dolycoris baccaum Linnée, 1758 & 0.51 & 0 & 0.44 \\
\hline & & Lygaeidae & Nysius sp. Dallas, 1852 & 4.18 & 0 & 0.65 \\
\hline & & & kleidocerys resedae Panzer, 1797 & 0.76 & 0 & 0.87 \\
\hline & & Reduvidae & Rhynocoris erythropus Linnée, 1767 & 0 & 0 & 1.09 \\
\hline & & & Reduvius sp. Fabricius, 1775 & 0.89 & 0 & 0 \\
\hline & & Cydnidae & Cydnus atterimus Forster, 1771 & 0 & 0 & 1.09 \\
\hline & Homoptera & Aphididae & Aphis fabae Scopoli, 1763 & 1.14 & 1.23 & 5.46 \\
\hline & & & Aphis pomi De Geer, 1773 & 1.52 & 0.70 & 3.71 \\
\hline & & & Dysaphis plantaginea Passerini, 1860 & 0 & 1.58 & 3.05 \\
\hline & Coleoptera & Apionidae & Apion sp. Schoenherr, 1823 & 0.89 & 1.40 & 2.84 \\
\hline & & Buprestidae & Anthaxia dimidiata Thunberg, 1789 & 1.77 & 0.35 & 1.31 \\
\hline & & Mordellidae & Variimorda villosa Schrank, 1781 & 2.28 & 0 & 1.09 \\
\hline & & Coccinelidae & Thea vigintiduopunctata Linnée, 1758 & 0.51 & 0.35 & 0.44 \\
\hline & & & Coccinella quatuordecimpunctata Linnée, 1758 & 0.38 & 0 & 0 \\
\hline & & & Coccinella algerica Kovář, 1977 & 5.32 & 0.70 & 2.84 \\
\hline & & & Hippodamia variegata Goeze, 1777 & 3.42 & 0.53 & 2.18 \\
\hline & & Bruchidae & Bruchidius sp. Fabricius, 1792 & 0.76 & 0 & 0 \\
\hline & & Cetoniidae & Oxytheria funesta Poda, 1761 & 4.94 & 1.23 & 1.09 \\
\hline & & Scarabaeidae & Scarabaeus sp. Linnée, 1758 & 0 & 2.64 & 0 \\
\hline & & & Geotropus sp. Linnée, 1758 & 0 & 1.40 & 0 \\
\hline & & & Rhizotrogus maculicollis Villa \& Villa, 1833 & 0 & 5.98 & 0 \\
\hline & & & Rhizotrogus aestivus Olivier, 1789 & 0 & 2.11 & 0 \\
\hline & & Carabidae & Carabus auratus Linnée, 1760 & 0.51 & 2.82 & 0 \\
\hline & & & Macrothorax morbilusus Fabricius, 1792 & 0 & 4.75 & 0 \\
\hline & & & Cicindella campestris Linnée, 1758 & 0 & 1.94 & 0 \\
\hline & & & Harpalus paratus Casey, 1924 & 0.25 & 6.51 & 0 \\
\hline & & & Bembidion sp. Latreille, 1802 & 0.76 & 4.58 & 0 \\
\hline & & Curculionidae & Lixus sp. Fabricius, 1801 & 1.14 & 2.64 & 0.44 \\
\hline & & & Phyllobius sp. Germar, 1824 & 1.65 & 1.23 & 1.09 \\
\hline & & Staphilinidae & Ocypus olens Muller, 1764 & 0 & 3.87 & 0 \\
\hline & & Elateridae & Drilus flavescens Olivier, 1790 & 0 & 3.35 & 0 \\
\hline & & & Agriotes lineatus Linnée, 1767 & 0 & 0.53 & 1.31 \\
\hline & & Meloidae & Meloe proscarabaeus Linnée, 1758 & 0 & 0.88 & 0 \\
\hline & & Histeridae & Hister sp. Linnée, 1758 & 0.25 & 0.53 & 0 \\
\hline & Dermaptera & Forficulidae & Forficula auricularia Linnée, 1758 & 0.38 & 2.29 & 0 \\
\hline & Orthoptera & Oedipodidae & Oedipoda germanica Latreille, 1804 & 0.63 & 1.23 & 0 \\
\hline & & Grillidae & Acheta domestica Linnée, 1758 & 0 & 0.88 & 0 \\
\hline & & & Grillus campestris Linnée, 1758 & 0.38 & 2.11 & 0 \\
\hline & & Acrididae & Anacridium aegyptium Linnée, 1764 & 0.76 & 0.53 & 0 \\
\hline & & Blattelidae & Ectobius sp. Stephens, 1835 & 0 & 1.06 & 0 \\
\hline & & Tetrigidae & Acrida ungarica Herbst, 1786 & 1.01 & 0 & 0 \\
\hline Total & 10 & 64 & 113 Species & 100 & 100 & 100 \\
\hline
\end{tabular}


The colored traps allowed us to collect 63 species, represented mainly by Coruna sp. with $6.77 \%$, may be parasitic of Aphis fabae with relative abundance of $5.46 \%$. The species Thomisius sp., Eupelmus sp., Sceliphron destillatorium, Calliphoridae sp., Syrphus ribesii, Fannia sp., Dolycoris baccaum, Thea vigintiduo punctata, and Lixus sp. presented a low centesimal frequency of $0.44 \%$.

Barber pot allowed us to collect 56 species, represented mainly by Harpalus paratus with relative abundance of $6.51 \%$ which are natural predators of various pests, followed by Rhysotrogus maculicolis with $5.99 \%$. The lowest relative abundance was recorded for the species Entomobrya nivalis with $0.18 \%$.
The sweep net allowed us to collect 80 species, represented mainly by the species Coccinella algerica with relative abundance of $5.32 \%$, followed by Nyisus sp. with relative abundance of $4.18 \%$ which are active natural predators of pests such as aphids. The species which presented a low centesimal frequency was Chrysoperla carnea, Componotus lateralis, Hister sp., Harpalus paratus, Anopheles sp, Brachonidae sp. recording a value of $0.25 \%$.

\subsection{Species centesimal frequency according to their trophic relationships}

The relative abundance obtained for species according to their trophic relationships is illustrated for sweep net (Fig. 2), for colored traps (Fig. 3) and for barber pots (Fig. 4).

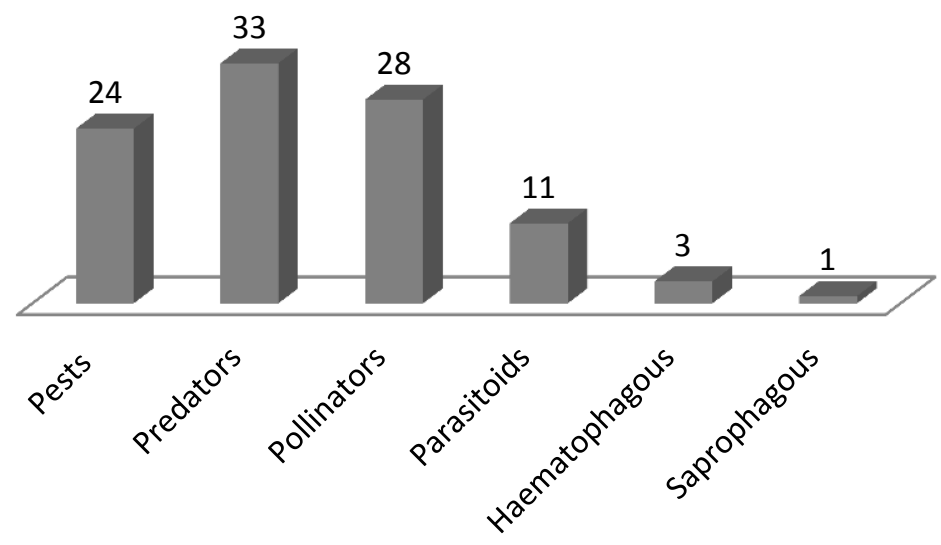

Figure 2: Relative frequency of species caught using sweep net following their diet

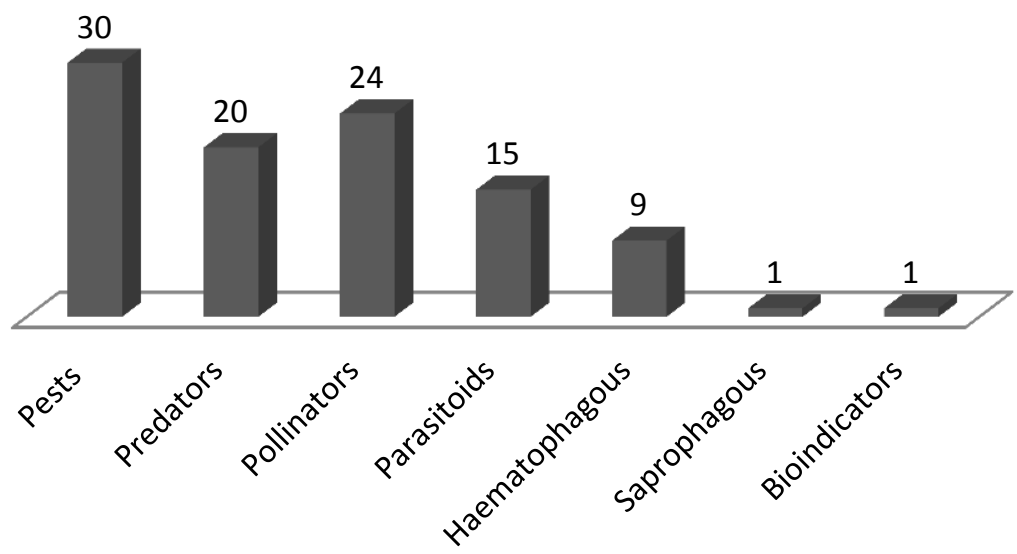

Figure 3: Relative frequency of species caught using colored traps following their diet. 


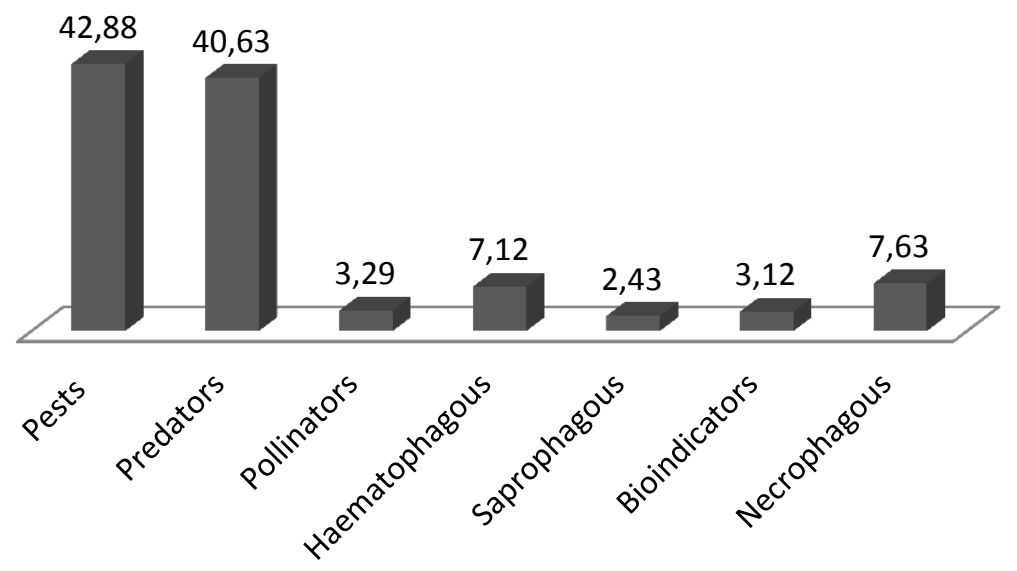

Figure 4: Relative frequency of species caught using barber pots following their diet

The best represented group using sweep net is predators with relative abundance of $33 \%$, whereas the least abundant group is saprophagous with only $1 \%$.

The best represented group using colored traps is pests with $30 \%$, whereas the least abundant group are saprophagous and bioindicators with only $1 \%$.

When using barber pots, the best represented group is pests with relative abundance of $42.88 \%$, while the group of saprophagous is the least represented recording only $2.43 \%$.

\subsection{Shannon Weaver diversity index and evenness index $(E)$}

Shannon-Weaver diversity index ( $\left.\mathrm{H}^{\prime}\right)$, maximum diversity (H'max.) and equitability (E) applied to species trapped by the different sampling techniques are presented in Figure 5.

\section{- $\mathrm{H}^{\prime}$}

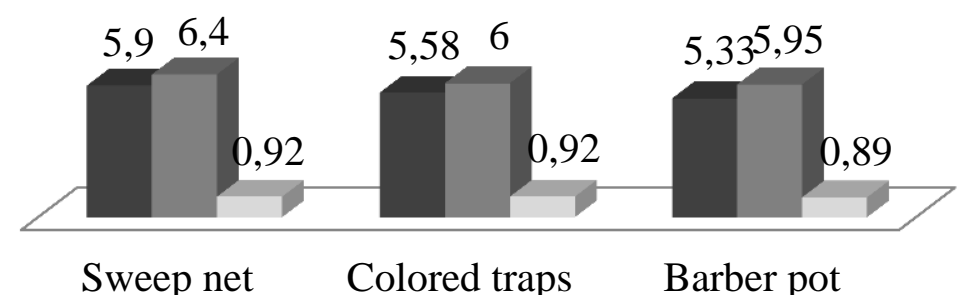

Figure 5: Shannon-Weaver diversity values $\mathrm{H}^{\prime}$ and evenness of species trapped by the various traps

Shannon-Weaver diversity values for the various species caught by trapping methods are equal to $\mathrm{H}^{\prime}=$ 5.90 bits; $\mathrm{H} \max =6.40$ bits for sweep net; $\mathrm{H}^{\prime}=5.58$ bits; $\mathrm{H}$ max $=6$ bits for colored traps and $\mathrm{H}^{\prime}=5.33$ bits; $\mathrm{H} \max =5.95$ bits for Barber pots. The species evenness values are $\mathrm{E}=0.92$ for the sweep net and colored traps; and $\mathrm{E}=0.89$ for barber pots. A fairly high evenness is recorded for three sampling methods (sweep net, colored traps and barber pots) this value approaches a value of 1 which reflects a balance between the middle of species. 


\section{DISCUSSIONS AND CONCLUSION}

The background knowledge of arthropods restricted to the apple crop in the region of Tizi Ouzou is a first step towards developing effective approaches for insect-pest control and for auxiliary species conservation. Our inventory upon ecological orchard not subjected to pesticide treatments, revealed 113 species distributed in 64 families belonging to 10 orders and to 3 classes.

Guettala-Frah (2009) has identified 348 insect species distributed in 97 families and 13 orders on apple orchard of the Aures region (Algeria) during three years (2001 to 2003).

(Allili, 2008) mentioned 23 species belonging to 19 families divided into eight levels of three classes in a pear orchard Birtouta (Algiers). (Frah et al., 2015) during his study on arthropodofauna in Sefiane (Batna) estimated the total wealth to $\mathrm{S}=71$ using barber pot, $\mathrm{S}$ $=63$ for colored traps, and $S=54$ for sweep net.

(Ounis et al., 2014) during an estimation of soil fauna biodiversity in an apricot orchard, report that the order of Coleoptera dominate with a percentage equal to $46.67 \%$.

According to the diet, (Guettala-Frah, 2009), in his study on the economic impact and bioecology of the main apple pests in the Aurés region, recorded $69.72 \%$ of pests, followed predators with a percentage equal to $15.98 \%$, and $4.76 \%$ for parasitoid. Finally, saprophages, necrophages and coprophages account for low levels of less than $3 \%$. (Mahdjane, 2013) obtained a frequency of $57.4 \%$ of pests, followed by predators with a value of $20.63 \%$ and polyphagous with $18.87 \%$, in her inventory of apple insects in Tadmait area, TiziOuzou.
According to (Blondel, 1979), a community is even more diversified as the diversity index is higher. (Guermah and Medjdoub-Bensaad, 2016) report a value of $\mathrm{H}=4.31$ bits with a maximum range of $\mathrm{H} \max =6.64$ bits applied to arthropods sampled by using the sweep net in the Tizi Ouzou region. Using the trapping trap technique for the study of arthropod biodiversity in 3 steppes in Djelfa area, (Guerzou et al., 2014) report variations in diversity values between 1.9 and 3.7 bits in Taicha, 3.02 and 3.5 bits in El Khayzar and 3.6 and 4.0 bits in Guayaza. (Frah et al., 2015) during his study on arthropodofauna upon an olive orchard in Sefiane (Batna) report a value of $\mathrm{H}=4.7$ bits, $\mathrm{Hmax}=6.1$ using barber pot; $\mathrm{H}=4.6$ bits, $\mathrm{Hmax}=6$ for colored traps and $\mathrm{H}=5.2$ bits, $\mathrm{Hmax}=5.8$ for sweep net. (Guermah and Medjdoub-Bensaad, 2016) found an evenness of 0.65; (Ounis and al., 2014) find a fairness varying from 0.12 to 0.47. (Frah et al., 2015) during his study on arthropodofauna upon an olive orchard in Sefiane (Batna) found an evenness of 0.77 using barber pot and colored traps, and 0.90 for sweep net.

The proliferation of arthropods and their diversity is favored by the absence of phytosanitary treatment in the study plot. Therefore, we notice the presence of a very varied auxiliary fauna composed of predators and parasitoids with significant values to maintain the pest populations at an economically acceptable level.

The identification of these arthropods and their trophic relationship constitutes an important scientific base, likely to contribute to the establishment of an appropriate integrated control strategy within these agro-ecosystems, from the perspective of an alternative approach to the use of pesticides and the preservation of biodiversity and the environment.

\section{REFERENCES}

Allili, F. (2008). Psylle du poirier Caccopsylla pyri (Homoptera : Psyllidae) à Birtouta, aux Eucalyptus et à Reghaïa : dynamique des populations, ennemis naturels et entomofaune associés. Thèse magister, ENSA, $182 \mathrm{p}$.

Barbault, R. (1981). Ecologie des populations et des peuplements. Edition Masson, Paris, 200 p.

Blondel, J. (1979). Biogéographie et écologie. Edition Masson, Paris, $173 \mathrm{p}$.

Chinery, M. (1988). Insectes d'Europe occidentale. Edition Arthraud, Paris, 307 p.

Chouinard, G. Firlej, A. Vanoosthuyse, F. et Vincent, C. (2000). «Guide d'identification des ravageurs du pommier et de leurs ennemis naturels ». Conseil des productions végétales du Québec inc., Québec. 69 p.

Clere, E. et Bretagnolle, V. (2001). Disponibilité alimentaire pour les oiseaux en milieu agricole : Biomasse et diversité des arthropodes capturés par la méthode des pots pièges. Revue d'écologie la terre \& la vie, 56, $275-297$.

Dajoz, R. (1971). Précis d'écologie, Edition Dunod, Paris, $434 \mathrm{p}$.

Debouzie, D et Thioulouse J. (1986). Statistics to Find Spatial and Temporal Structures in Populations. Pest Control: Operations and Systems Analysis in 
Dyhia GUERMAH et al.

Fruit Fly Management, 263-282. https://doi.org/10.1007/978-3-642-70883-1_18

Delvare, G. et Aberlenc, H.P. (1989). Les insectes d'Afrique et d'Amérique tropicale. Clé pour la reconnaissance des familles. Ed. Cirad, France, 298 p.

Dubuis, P. H. (2010). Revue suisse viticulture, arboriculture, horticulture, 42(1), 7.

Frah, N., Baala, H., Loucif, A. (2015). Etude d'arthropodofaune dans un verger d'olivier à Séfiane (wilaya de Batna Est Algérien). Lebanese Science Journal, 16(2), 37-45.

Guermah, D. and Medjdoub-Bensaad, F. (2016). Inventory of arthropoda fauna in apple plot of Dorset golden variety in de Tizi-Ouzou region of Algeria. Journal of Humanities, Arts, Medicine and Sciences, 2, 57-62.

Guerzou, A., Derdouk, W., Guerzou, M. and Doumandji, S. (2014). Arthropod diversity in 3 step region of Djelfa area (Algeria). International Journal of Zoology and Research, 4, 41-50.

Guettala-Frah, N. (2009). Entomofaune, Impact Economique et Bio- Ecologie des principaux Ravageurs du Pommier dans la région des Aurès. Thèse doctorat, Université Batna, 166P.

Mahdjane, H. (2013). Inventaire qualitatif et quantitatif des insectes inféodés au prunier dans la région de
Tadmait dans la région de Tizi-Ouzou. Thèse magister, université de Tizi Ouzou, $86 \mathrm{p}$.

Ounis, F., Frah, N. \& Medjdoub-Bensaad, F. (2014). Diversité de la faune du sol dans une parcelle d'abricotier à Takout (Batna, Est de l'Algérie). International Journal of Agriculture Innovation and Research, 2(4), 542-54.

Perrier, R. (1927). La faune de la France illustrée. Coléoptères, partie 1. Tome 5. Ed Reprint, Aubin. Paris, 192 p.

Perrier, R. (1932). La faune de la France illustrée. Coléoptères. Tome 2. Edition Delagrave. Paris, 229 p.

Perrier, R. (1961). La faune de la France, Tome V: les coléoptères. Edition Delagrave, Paris, $230 \mathrm{p}$.

Piham, J. C. (1986). Les Insectes. Paris, 160 p.

Ramade, F. (2003). Eléments d'écologie, écologie fondamentale. 3éme Edition Dunod, France, 690 p.

Seguy, E. (1923). Les moustiques d'Europe. Ed., Paul Le chevalier, Paris, $234 \mathrm{p}$.

Seguy, E. (1924). Les moustiques de l'Afrique mineure, de l'Egypte et de Syrie. Encyclopédie entomologique. Ed., Paul Le chevalier, Paris, 257 p.

Sergent, E. (1909). Détermination des insectes piqueurs et suceurs de sang. Ed Octave Doin et Fils, Paris, $308 \mathrm{p}$. 